\title{
Archaeobotanical studies at Suabarei, Puri district, Odisha, India
}

\author{
Satish S. Naik ${ }^{1, *}$, Jeeban Kumar Patnaik ${ }^{2, *}$, Eleanor Kingwell-Banham ${ }^{3}$, \\ Charlene Murphy ${ }^{3}$ and Dorian Q. Fuller ${ }^{3}$
}

\author{
${ }^{1}$ Department of AIHC and Archaeology, Deccan College Post-Graduate and Research Institute, Deemed to be University, Pune 411006, India \\ ${ }^{2}$ Excavation Branch-IV, Archaeological Survey of India, Bhubaneswar 751 002, India \\ ${ }^{3}$ UCL Institute of Archaeology, 31-34 Gordon Square, University College London, WC1H 0PY, UK
}

\begin{abstract}
This article presents the results of archaeobotanical analysis of charred plant remains from Suabarei, a Neolithic-Chalcolithic mounded settlement site situated in Puri district, Odisha, India. A single rice grain has provided a new radiocarbon date of 3370 3210 cal BP. Crops identified include rice (Oryza sativa cf. subsp. indica), horse gram (Macrotyloma uniflorum), green gram/mung bean (Vigna radiata) and possibly some millets, including browntop millet (Brachiaria ramosa). Suabarei is part of the agricultural mounded settlement group that existed during the Chalcolithic period of the eastern fertile plains of India and the data recovered from this site provide only the third complete archaeobotanical dataset for this cultural group.
\end{abstract}

Keywords: Archaeobotanical analysis, charred plant remains, mounded settlement, rice millet.

SUABAREI is a mounded Neolithic-Chalcolithic settlement site situated in the lowlands of Puri district, Odisha, India $\left(20^{\circ} 09^{\prime} 14^{\prime \prime} \mathrm{N}, 85^{\circ} 48^{\prime} 33^{\prime \prime} \mathrm{E}\right)$ (Figure 1). Excavations were carried out at the site in 2015-2016 under the supervison of Jeeban Kumar Patnaik (Archaeological Survey of India (ASI)). They revealed a $6 \mathrm{~m}$ deep sequence comprised of a short Neolithic phase, followed by a hiatus and a deep series (4-5 m) of Chalcolithic layers. Circular floor plans with central hearths were identified within the Chalcolithic layers; however, none was discovered in the Neolithic level (Figures 2 and 3). The range of finds recovered from the Neolithic material was low. Chalcolithic finds included a rich variety of decorated pottery types, bone points, copper rings and fish hooks, semi-precious stone beads, polished celts and stone fish net or loom weights ${ }^{1,2}$.

The fertile coastal plain of Odisha is drained by several important rivers and their tributaries, including the Daya River and the Gangua rivulet, providing an ideal environment for summer crops ${ }^{1,2}$. This area is dotted with mounded Neolithic-Chalcolithic settlement sites, dating between 4000 and $3000 \mathrm{yrs}$ BP, generally located along

*For correspondence. (e-mail: psatishnaik@gmail.com; jeeban84@gmail.com) the edge of rivers, which have produced archaeobotanical evidence for rice and pulse agriculture. Previous sites excavated in this area include Golbai Sasan, Khameswaripalli, Gopalpur and Harirajpur (Figure 1) $)^{3-10}$. However, among all of these sites, Neolithic levels have only been uncovered at Golbai Sasan. Nevertheless, previous studies have shown that Neolithic-Chalcolithic people in Odisha were subsisting on a diet of wild ungulates and river fish, domestic sheep/goat and cattle ${ }^{11}$, domestic rice, pulses and, possibly, some cultivated millets ${ }^{10}$. There is also evidence that Citrus trees were being cultivated here before the end of the Chalcolithic period (3500$3000 \mathrm{BP})^{12}$. Joglekar and Patnaik ${ }^{11}$ have provided preliminary data on the faunal remains from Chalcolithic Suabarei showing that cattle and goat were of primary importance at this site. Other important faunal species included freshwater fish and wild game from the grasslands and forests. This evidence shows that the people of Suabarei were exploiting their wider local environment in a variety of ways beside agriculture, from fishing to hunting forest animals, possibly with the assistance of dogs which have also been identified at this site. The present archaeobotanical study provides insights into the plant foods utilized at Suabarei, consolidating our knowledge of agriculture practised in Chalcolithic Odisha.

\section{Materials and methods}

The archaeobotanical remains were collected from habitation deposits, following visual inspection during the course of the excavations. Six soil samples from trench A $1 / 2$, two from A2/1, one from A $3 / 3$ and three from A5/3 (20 kg each) were taken from the Chalcolithic levels, while one sample from trench A1/2 $(80 \mathrm{~kg})$ was taken from the Neolithic level. These samples were floated using bucket flotation to retrieve the carbonized and silicified plant remains using $0.25 \mathrm{~mm}$ mesh geological sieve. The plant remains were segregated and categorized under a low-power stereo microscope (WILD Heerbrugg M200) at the Palaeobotany Laboratory in Deccan College, Pune, India and photographs of each recorded taxa were taken. Most of the seeds/grains of crop plants, weedy taxa and fruit remains were found in a good state of 


\section{RESEARCH ARTICLES}

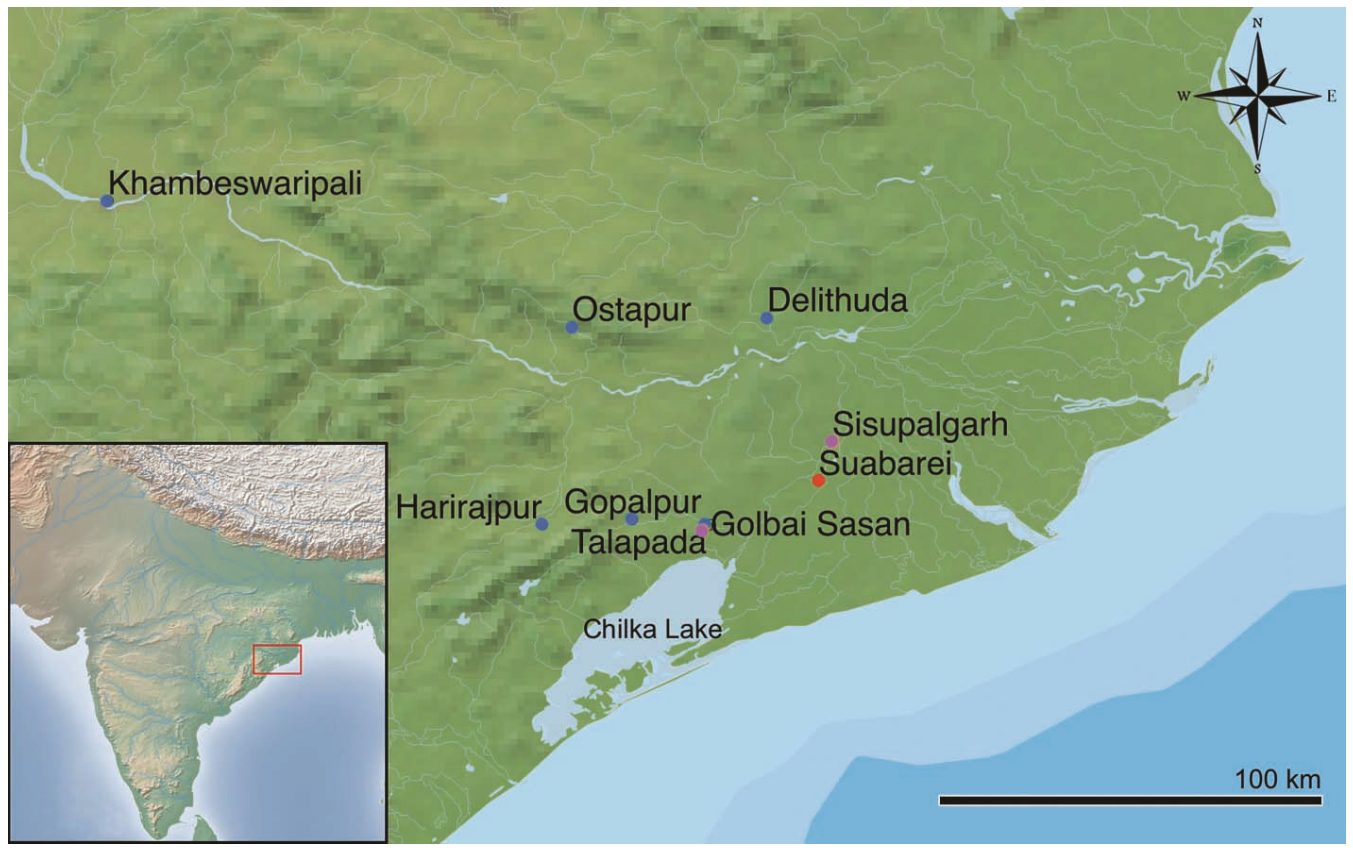

Figure 1. Map of Odisha, India showing the location of selected excavated mounded Neolithic-Chalcolithic sites (blue dots), Early historic settlements (purple dots) and Suabarei (red dot).
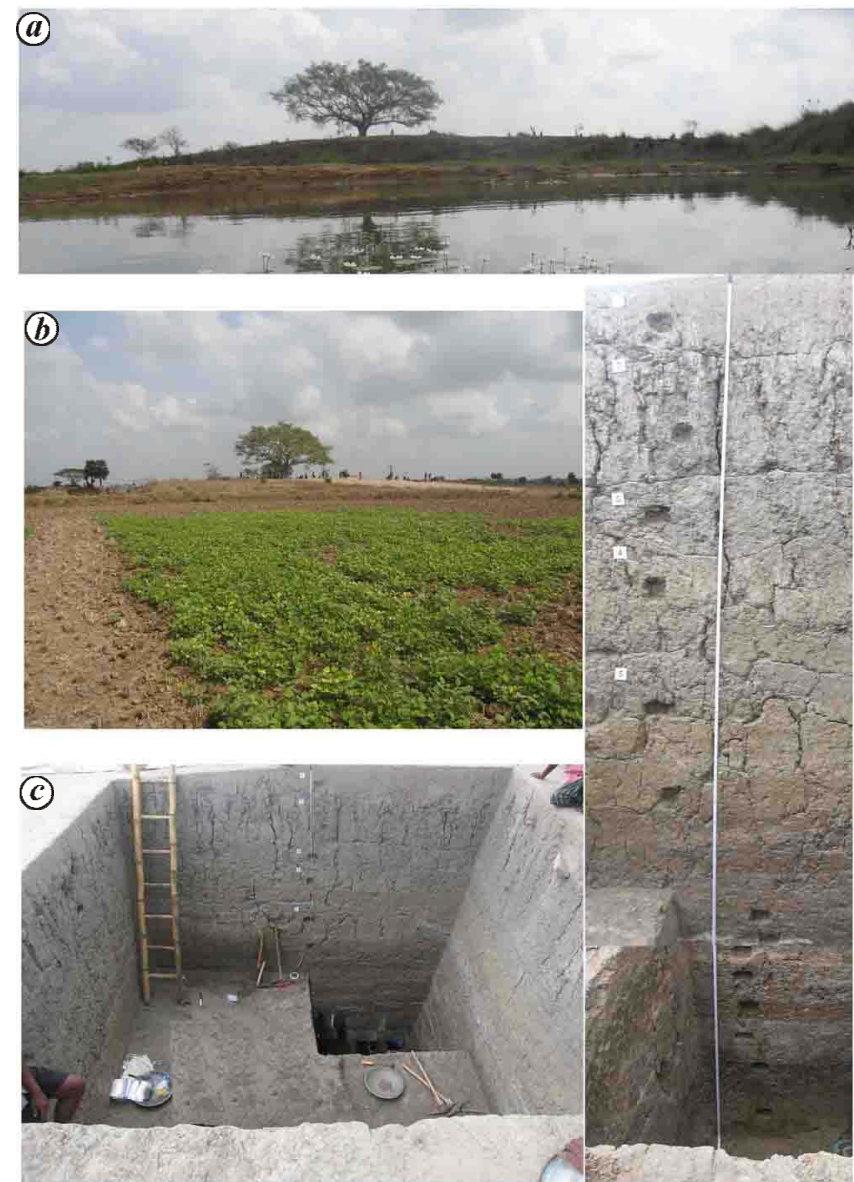

Figure 2. Archaeological site of Suabarei. a, General view showing the settlement mound with a tree on the top. $\boldsymbol{b}$, Site view from the west. $\boldsymbol{c}$, View of the trench A1. $\boldsymbol{d}$, Section facing east after soil sampling.
Trench No. XBI Qd.2 East facing

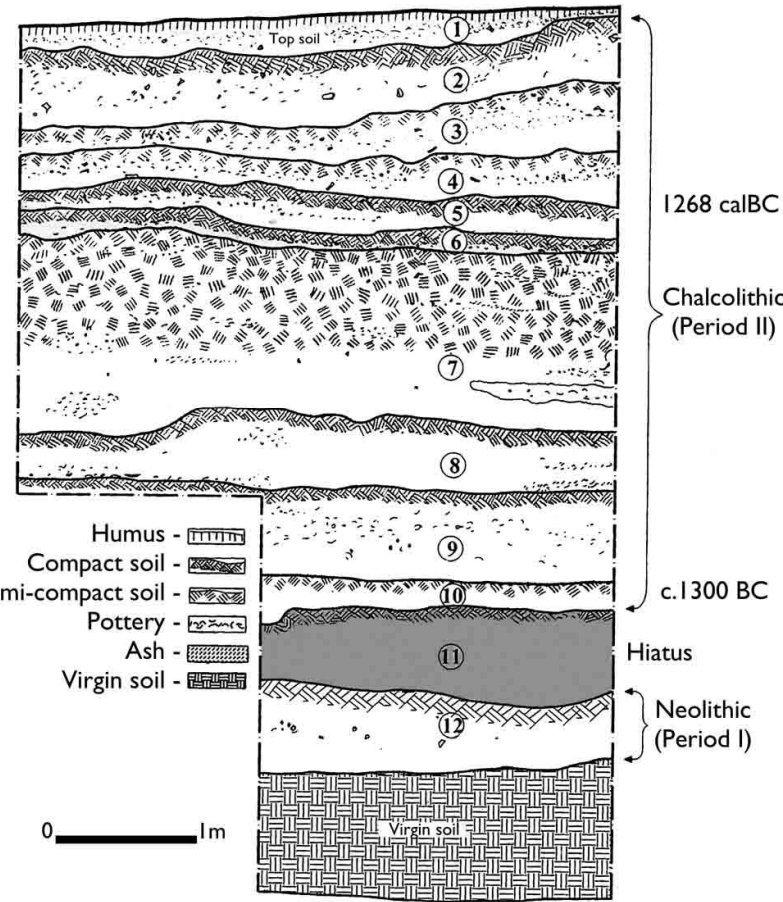

Figure 3. Stratigraphic sequence, trench XB1, quadrant 2. Sequence is the same across all trenches.

preservation. However, in a few cases severe carbonization prevented survival of diagnostic features. Grains and seeds were measured using a stage micrometer and an ocular disc. Identifications were made using the reference 
RESEARCH ARTICLES

Table 1. Radiocarbon dates

\begin{tabular}{|c|c|c|c|c|c|c|}
\hline Lab ID* & Stratigraphic position & Material & Delta ${ }^{13} \mathrm{C}$ & Date BP & Calibrated date (BP) $2 \sigma$ & Median date (BP) \\
\hline SUERC-73797 & Chalcolithic; layer 5, 1.96-2.24 m & Charred rice (Oryza sp.) & -26.3 & $3083 \pm 29$ & $3370-2950$ & 3160 \\
\hline Beta-434597 & Chalcolithic; layer 9, 3.45-3.6 m & Wood charcoal & -25.3 & $2900 \pm 30$ & $3160-2950$ & 3055 \\
\hline Beta-434011 & Chalcolithic, layer 10 , below $3.65 \mathrm{~m}$ & Wood charcoal & -24.9 & $2980 \pm 30$ & $3321-3061$ & 3191 \\
\hline Beta-434012 & Neolithic; layer $11,4.85-5.7 \mathrm{~m}$ & Wood charcoal & -26.4 & $3460 \pm 30$ & $3840-3640$ & 3740 \\
\hline
\end{tabular}

*All radiocarbon dates were sent to SUERC or Beta Analytic. Standard pre-treatment methods were used (acid/alkaline washes). OxCal.v.4.3.2 and IntCal14 Bayesian sequence models were used.

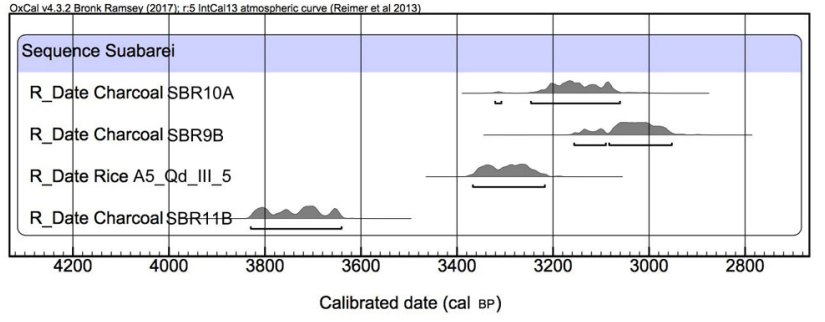

Figure 4. Oxcal calibration of radiocarbon dates. OxCal.v.4.3.2 and IntCal14 Bayesian sequence model were used ${ }^{26-29}$.

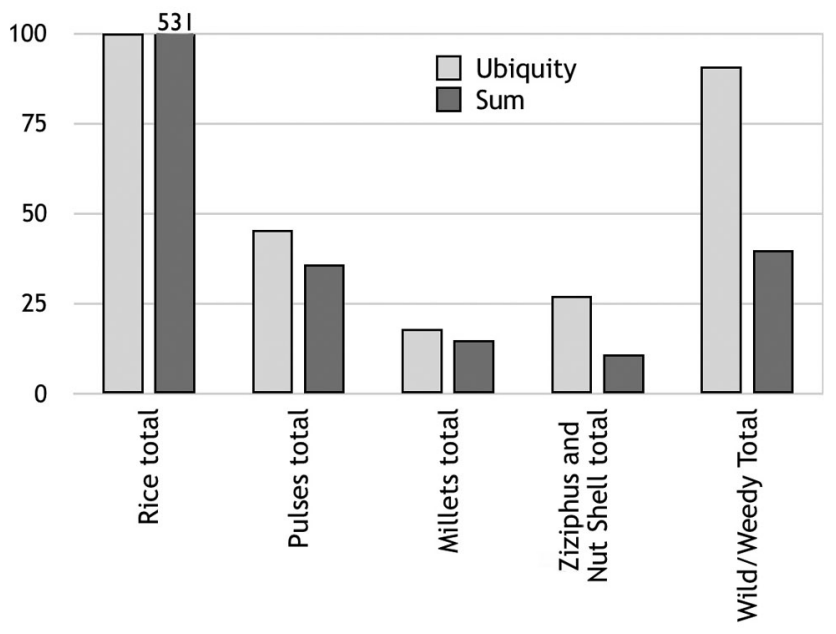

Figure 5. Ubiquity (\%) and total sum of plant remains recovered.

collection housed at Deccan College, and relevant published material ${ }^{13-16}$.

\section{Results and discussion}

\section{Radiocarbon dating}

A charred cut rice grain from the Chalcolithic phase was sent for radiocarbon dating (SUERC-73797, UK) and returned a date of $3083 \pm 29$ (3370-3210 cal BP) (Table 1). Additionally, three bulk wood charcoal samples were sent for radiocarbon dates (Beta Analytic., USA). The sample from the Neolithic phase returned a date of 3840 3640 BP, while Chalcolithic phase wood charcoal samples

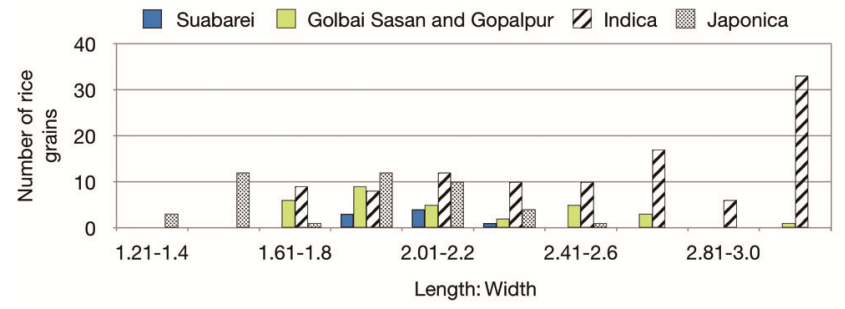

Figure 6. Length : width ratio of measured Oryza sativa, compared to published ratios by Castillo et al ${ }^{18}$ for indica and japonica subspecies, and combined data for Golbai Sasan and Gopalpur ${ }^{17}$.

returned a date of 3370-2950 BP. It therefore appears that there was a c. 500 year hiatus between the initial Neolithic settlement and subsequent Chalcolithic settlement (Figure 4).

\section{Archaeobotanical results}

No macrobotanical remains were found from the Neolithic sample; however, several taxa were identified within the Chalcolithic samples (Table 2). Rice (Oryza sativa cf. subsp. indica) (Figure 5) showed its abundance, making up $90.74 \%$ of the total assemblage, suggesting that it was the principal crop at Suabarei. The length : width data for measurable rice grains (Figure 6) showed that limited data from Suabarei cannot be used to assign sub-species. However, considering these data in combination with those from Golbai Sasan and Gopalpur, KingwellBanham et al. ${ }^{17}$ suggested that Chalcolithic rice in Odisha may have been a mixed population of $O$. sativa japonica and $O$. sativa indica. This is in agreement with metric and archaeogenetic data from the later early historic sites of Ter and Balathal, which also showed that mixed populations of indica and japonica rice were being grown at the sites $^{18}$.

Description of the botanical remains is given below.

\section{Cereals}

Oryza sativa L. (rice; Figure $7 a-g$ ): These were recovered in the form of whole grains, fragmented grains, detached embryos, grain fragments with embryos, immature grains, immature grain fragments, immature grain 
Table 2. Archaeobotanical remains

\begin{tabular}{|c|c|c|c|c|c|c|c|c|c|c|c|c|c|c|}
\hline & \multirow{2}{*}{$\begin{array}{l}\text { Trench/Quadrant/ } \\
\text { stratum }\end{array}$} & \multicolumn{12}{|c|}{ Chalcolithic } & \multirow{2}{*}{$\begin{array}{c}\text { Neo } \\
\begin{array}{c}\text { A } 1 / 2 / \\
12\end{array}\end{array}$} \\
\hline & & $\begin{array}{l}\text { A2/ } \\
1 / 2\end{array}$ & $\begin{array}{l}\text { A2/ } \\
1 / 2\end{array}$ & $\begin{array}{l}\text { A5/ } \\
3 / 5\end{array}$ & $\begin{array}{l}\text { A5/ } \\
3 / 5\end{array}$ & $\begin{array}{l}\text { A5/ } \\
3 / 6\end{array}$ & $\begin{array}{l}\text { A3/ } \\
3 / 6\end{array}$ & $\begin{array}{l}\text { A1/ } \\
2 / 6\end{array}$ & $\begin{array}{l}\text { A1/ } \\
2 / 7\end{array}$ & $\begin{array}{l}\text { A1/ } \\
2 / 8\end{array}$ & $\begin{array}{l}\text { A1/ } \\
2 / 9\end{array}$ & $\begin{array}{c}\mathrm{A} 1 / 2 / \\
10\end{array}$ & $\begin{array}{c}\mathrm{A} 1 / 2 / \\
11\end{array}$ & \\
\hline & $\begin{array}{l}\text { Phase no. } \\
\text { (depth, cm) }\end{array}$ & 62 & 80 & $\begin{array}{c}196 \text { to } \\
224\end{array}$ & $\begin{array}{c}225 \text { to } \\
258\end{array}$ & $\begin{array}{c}258 \text { to } \\
278\end{array}$ & 270 & 277 & & $\begin{array}{c}368 \text { to } \\
388\end{array}$ & 390 & 400 & $\begin{array}{c}457 \text { to } \\
486\end{array}$ & $\begin{array}{c}565 \text { to } \\
583\end{array}$ \\
\hline Scientific name & Common name & & & & & & & & & & & & & \\
\hline \multicolumn{15}{|l|}{ Cereals } \\
\hline Oryza sativa & Rice grain whole & & 4 & 4 & 2 & 1 & 3 & 1 & 2 & & 2 & & & \\
\hline Oryza sativa & $\begin{array}{l}\text { Rice grain } \\
\text { fragmented }\end{array}$ & 5 & & 1 & 1 & 10 & 45 & 4 & 27 & 16 & 256 & 12 & & \\
\hline Oryza sativa & Rice embryo & & & & & & 4 & & & & & & & \\
\hline Oryza sativa & Immature rice grain & & & & & & 2 & 5 & 1 & & & & & \\
\hline Oryza sativa & $\begin{array}{l}\text { Immature rice } \\
\text { fragmented }\end{array}$ & & & & & & 37 & & 44 & & 6 & & & \\
\hline Oryza sativa & $\begin{array}{l}\text { Immature rice } \\
\text { embryo ends }\end{array}$ & & & & & & 6 & 1 & 5 & & 4 & & & \\
\hline Oryza sativa & $\begin{array}{l}\text { Cultivated rice } \\
\text { spikelet bases }\end{array}$ & 4 & & & & & 2 & & & & & & & \\
\hline Oryza sp. & $\begin{array}{l}\text { Immature spikelet } \\
\text { bases }\end{array}$ & & & & & & 1 & & & & & & & \\
\hline Oryza sp. & Wild spikelet base & & & & & & 1 & & & & & & & \\
\hline $\begin{array}{l}\text { Macrotyloma } \\
\text { uniflorum }\end{array}$ & Horsegram & & & & & & 1 & & & & 1 & & & \\
\hline Macrotyloma & Horsegram & & & & & & & & & & & & & \\
\hline uniflorum & fragmented & & & & & & 1 & & 4 & 2 & 24 & 2 & & \\
\hline Vigna radiata & Greengram & & & & & & & & 1 & & & & & \\
\hline Echinochloa sp. & Barnyard millet & & & & & & 8 & & & & & & & \\
\hline Nut shell indet. & & & & & & & 6 & & 3 & & & & & \\
\hline Ziziphus sp. & Jujube & & & & & 1 & 1 & & & & & & & \\
\hline Cenchrus cf. ciliaris & Anjan-grass & & & & & & & & & & 1 & & & \\
\hline Cleome cf. gynandra & Spider flower & & & & & & 1 & & & & 1 & & & \\
\hline Cyperus sp. & Sedge & 1 & & & & & & & & & & & & \\
\hline Eleocharis sp. & Spike sedge & 1 & & & & & & & & & & & & \\
\hline Eleusine indica & $\begin{array}{l}\text { Indian goose- } \\
\text { grass }\end{array}$ & & & & & & & & & & & 2 & & \\
\hline Fimbristylis sp. & & 1 & & & & & 2 & & & & 1 & & & \\
\hline Panicum sp. & & & & & & 1 & 1 & & & & 1 & 1 & & \\
\hline Oryza cf. rufipogon & Wild rice & & & 1 & 1 & & & & 1 & & & 1 & & \\
\hline Oryza cf. rufipogon & $\begin{array}{l}\text { Wild rice } \\
\text { fragmented }\end{array}$ & & & & & & 2 & & 3 & & 4 & 1 & & \\
\hline Oryza cf. rufipogon & Wild rice embryo & & & & & & & & 1 & & & & & \\
\hline Rumex sp. & & 1 & 1 & & & & 1 & & & 1 & & & & \\
\hline Scirpus triqueter & Triangular club-rush & & & & & & 1 & & & 1 & & & & \\
\hline Scrophulariaceae & & & & & & & & & & & 1 & & & \\
\hline Setaria sp. & & & & & & & & & & & 1 & & & \\
\hline Silene conoidea & Catchfly & & & & & & 1 & & & & 1 & & & \\
\hline Solanum sp. & & 2 & & & & & & & & & & & & \\
\hline $\begin{array}{l}\text { Wood charcoal } \\
\text { fragments }\end{array}$ & & & & & 1 & & & & 15 & & 137 & 28 & 6 & 4 \\
\hline
\end{tabular}

fragments with embryos and spikelet bases of mature and immature rice grains. The whole rice grains were elongate to narrowly oblong, laterally flattened and prominently ribbed. Husk was noted on a few grains, but not quantified. Mature grains of $O$. sativa were measured following the methodology of Castillo et al. ${ }^{18}$ (Table 3, Figure 5).

Oryza rufipogon Griffith (wild rice; Figure $7 h$ ): A wild weedy species of rice was occasionally harvested along with the cultivated crop. These were recovered in the 
RESEARCH ARTICLES
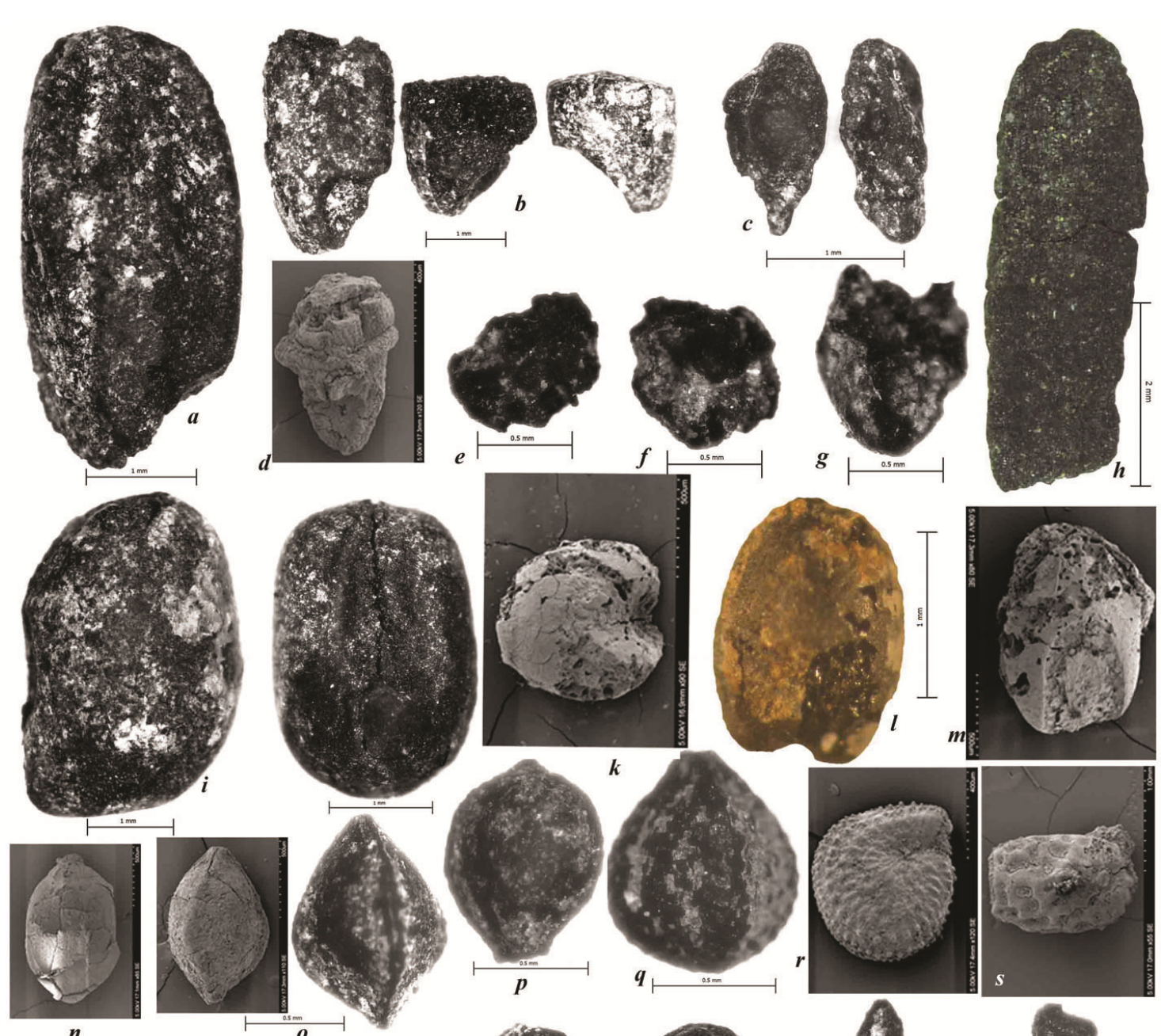

$f$

g
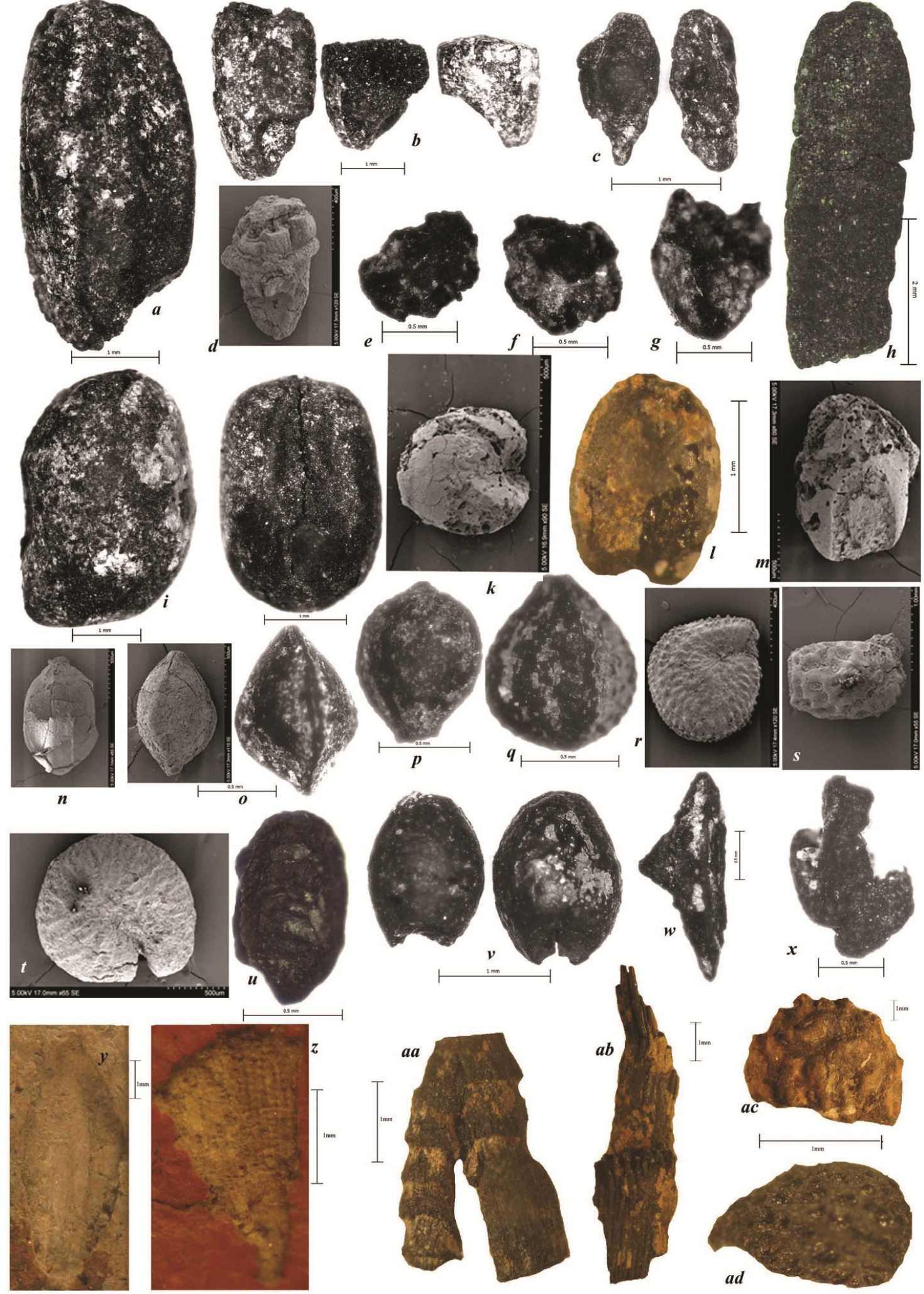

Figure 7. Archaeobotanical remains at Suabarei: $\boldsymbol{a}-\boldsymbol{g}$, Rice (Oryza sativa L.); $\boldsymbol{h}$, Wild rice (Oryza rufipogon Griffith); $\boldsymbol{i}$, Horsegram (Macrotyloma uniflorum (Lam.) Verdc); $\boldsymbol{j}$, Greengram (Vigna radiata (L.) Wilczek); $\boldsymbol{k}$, Browntop millet (Brachiaria ramosa (L.) Stapf.); $\boldsymbol{l}$, Raishan millet (Digitaria cf. cruciata (Nees) A. Camus.); $\boldsymbol{m}$, Barnyard millet (Echinochloa sp.); $\boldsymbol{n}$, Anjan grass (Cenchrus cf. ciliaris L.); o, Knotweed (Rumex sp.); $\boldsymbol{p}$, Spike sedge (Elaeocharis sp.); $\boldsymbol{q}$, Club-rush (Scirpus triqueter L.); $\boldsymbol{r}$, Catchfly (Silene conoidea L.); $\boldsymbol{s}$, Scrophulariaceae; $\boldsymbol{t}$, Spider flower (Cleome cf. gynandra L.); $\boldsymbol{u}$, Indian goose-grass (Eleusine indica (L.) Gaertn.); $\boldsymbol{v}$, Panicum sp.; $\boldsymbol{w}$, Thorn, unidentifiable to species; $\boldsymbol{x}$, Solanum sp.; $\boldsymbol{y}, \boldsymbol{z}$, Rice husk impression (Oryza cf. sativa); a a, Culm base of grass; ab, Culm node of grass; ac, Cut seed of Zyzyphus sp. (jujube), ad, Indeterminate seed. 
Table 3. Measurements of charred rice (Oryza sp.)

\begin{tabular}{lcccccc}
\hline Phase & Context & Depth $(\mathrm{cm})$ & Length $(\mathrm{cm})$ & Width $(\mathrm{cm})$ & Breadth $(\mathrm{cm})$ & $L / W$ ratio \\
\hline A1/Qd 2 & Stratum 6 & 270 & 4.39 & 1.92 & 1.69 & 2.28 \\
A1/Qd 2 & Stratum 6 & 270 & 3.72 & 1.74 & 1.42 & 2.13 \\
A1/Qd 2 & Stratum 6 & 270 & 3.15 & 1.43 & 1.18 & 2.20 \\
A1/Qd 2 & Stratum 6 & 277 & 3.94 & 2.06 & 1.54 & 1.91 \\
A1/Qd 2 & Stratum 6 & 278 & 4.26 & 2.07 & 1.43 & 2.05 \\
A1/Qd 2 & Stratum 7 & n/a & 4.84 & 2.21 & 1.47 & 2.19 \\
A1/Qd 2 & Stratum 7 & n/a & 4.43 & 2.27 & 1.5 & 1.95 \\
A1/Qd 2 & Stratum 9 & 3.90 & 4.33 & 2.18 & 1.67 & 1.98 \\
A1/Qd 2 & Stratum 9 & 3.90 & 4.05 & 1.89 & 1.5 & 2.14 \\
\hline
\end{tabular}

Table 4. Measurements of charred horse gram

\begin{tabular}{lcccccc}
\hline Phase & Context & Depth $(\mathrm{cm})$ & Length $(\mathrm{cm})$ & Width $(\mathrm{cm})$ & Breadth $(\mathrm{cm})$ & $L / W$ ratio \\
\hline A1/Qd 2 & Stratum 6 & 270 & 3.69 & 2.47 & 1.95 & 1.49 \\
A1/Qd 2 & Stratum 9 & 390 & 3.59 & 2.68 & 1.74 & 1.33 \\
\hline
\end{tabular}

form of whole grains, fragmented grains and grain fragments with embryos (15 nos). The grains were comparatively more slender than cultivated rice, elongate to narrowly oblong and without husk.

\section{Pulses}

Macrotyloma uniflorum (Lam.) Verdc. (horse gram; Figure $7 i$ ): These were ellipsoidal, somewhat kidney-shaped and laterally flattened, whole and fragmented seeds with smooth seed coats recovered from the Chalcolithic period. The complete horsegram seeds present in the assemblage were measured (Table 4) ${ }^{19}$.

Vigna radiata (L.) Wilczek (green gram/mung bean; Figure $7 j$ ): A single complete carbonized grain was recovered from layer 7 of Chalcolithic cultural level. The seed was elongated and somewhat cylindrical in appearance. It was characterized by squarish to rounded ends. A flat and elliptical hilum was situated at the level of seedcoat surface.

\section{Millets}

Brachiaria ramosa (L.) Stapf. (browntop millet; Figure $7 \mathrm{k}$ ): Three grains of browntop millet were recorded from layer 2. The seeds are broadly elliptic with a smoothsurfaced pericarp. The plant commonly occurs in wet places such as rice fields, along ditches and canals, and in marshes.

Digitaria cf. cruciata (Nees) A. Camus (Raishan millet; Figure $7 l$ ): Two complete grains of domesticated minor millet Digitaria were recovered from the Chalcolithic levels. The seeds were thin and pointed, with a small embryo. It is a rainfed crop and consumed mainly as a substitute for rice. The straw of Raishan is useful as fodder for cattle.
Echinochloa sp. (barnyard millet; Figure $7 \mathrm{~m}$ ): The grains were rounded, with a smooth surface and wellmarked hilum scar. It is a type of wild grass usually found in waterlogged areas and as a weed in the paddy fields.

\section{Wild and weedy taxa}

Cenchrus cf. ciliaris L. (anjan grass; Figure $7 n$ ): A charred single, ovate, hulled caryopsis with rugose surface.

Rumex sp. (knotweed; Figure $7 o$ ): Complete nutlets were recovered from different Chalcolithic levels. They were stalked and triangular in shape. The plants are commonly found in shallow fresh or brackish water; pools, marshy sites, along drains; lowland-irrigated and tidal rice fields, often abundant and gregarious.

Eleocharis sp. (spike sedge; Figure $7 p$ ): A few nutlets of spike sedge were recovered from layers 2 and 7 . The nutlets were biconvex or plano-convex, smooth or faintly reticulate, triangular and compressed. These plants commonly occur in swamps, streams, rivers, ponds and lake margins.

Scirpus triqueter L. (club-rush; Figure $7 q$ ): The nutlets were trigonous with a reticulate surface, and were recovered from layers 6 and 9. These plants are commonly found in river banks, lakes and rice fields.

Silene conoidea L. (catchfly; Figure $7 r$ ): Two seeds of catchfly were recovered from layers 6 and 9. The seeds were very small and flattened with rounded margin. They had shiny and warty surface with distinct tubercles on the seed coat.

Scrophulariaceae (Figure 7s): A single carbonized seed, rectangular in shape, broadly pitted on all sides, was recovered from layer 7 .

Cleome cf. gynandra L. (spider flower; Figure $7 t$ ): Two reniform seeds, compressed and conspicuously 
tuberculoid, were recovered from layers 6 and 9. This is a weed of wastelands and cultivated fields.

Eleusine indica (L.) Gaertn. (Indian goose-grass; Figure $7 u$ ): Two seeds of goose-grass were documented from layer 10. They had distinctive undulations on the seed coat. It is a serious weed of rice crop.

Panicum sp. (Figure $7 v$ ): A few grains of wild Panicum sp. were recovered from layers 6 and 9. The grains were broadly elliptical. It is good fodder for cattle.

Thorn, unidentifiable to species (Figure $7 w$ ).

Solanum sp. (Figure 7x): A couple of seeds were noted from layer 2.

Oryza cf. sativa (rice husk impression; Figure $7 y$ and $z$ ): Rice husk impressions were observed on many potsherds at the site ${ }^{1}$. The impressions were elongate to narrowly oblong, with prominent ribs across the lemma and palea ${ }^{1}$. Some impressions represented the typical chess-board pattern of rice husk on the potsherd.

Culm base of grass (Figure $7 a a$ ).

Culm node of grass (Figure $7 a b$ ).

\section{Fruits and nuts}

Ziziphus sp. (jujube; Figure 7 ac): Globose or somewhat oval fragmented stone. The stone pieces had tuberculoid patterning on the surface.

Indeterminate (Figure $7 \mathrm{ad}$ ).

Pulses (horse gram and a single find of green gram/ mung bean) made up $3.43 \%$ of the total assemblage (Figure 5). Horse gram ( $M$. uniflorum) is a drought-resistant plant and a rich source of vegetable protein, with the highest calcium content among pulses ${ }^{19}$. Both of these pulses were reported by Harvey et al..$^{20}$ from the NeolithicChalcolithic site of Golbai Sasan, and horse gram was also identified at Chalcolithic Gopalpur.

Jujube (Ziziphus sp.) and unidentified nut shells (1.04\% of the total assemblage) may have been eaten cooked or raw. These plants would have been available locally in wild state. The flesh of wild seeds is consumed and stone spitted out randomly, which grows as zarberi shrubs. Significant quantities of nut shell and fruit peel (unfortunately as yet unidentified to species), and Citrus sp. rind have previously been reported from Gopalpur, and this additional information from Suabarei adds to the implication that tree crops were important resources in Chalcolithic Odisha. Wild and weedy taxa represented $4.77 \%$ of the total assemblage (Figure 5). These included wild rice (O. rufipogon), barnyard millet (Echinochloa sp.), anjan grass (Cenchrus cf. ciliaris), knotweed (Rumex sp.), spike sedge (Elaeocharis sp.), club-rush (S. triqueter), catchfly (S. conoidea), Scrophulariaceae, spider flower (Cleome cf. gynandra), Indian goose-grass (E. indica), Panicum sp. and Solanum sp. All these are plausibly weeds of agricultural rice fields, but equally may have been incorporated into the assemblage as weeds of the settlement or natural background vegetation.
Three seeds of browntop millet (B. ramosa) were recovered from Suabarei. It has also been identified at Golbai Sasan, but again only in low numbers. It is unclear if browntop millet was a crop in Chalcolithic Odisha, or it represents a weed of rice. Based on the current low number of finds it seems more likely that it was a weed during this period. However, it is worth noting that browntop millet appears to have been an important staple food in Neolithic South India ${ }^{21}$. Although it is usually regarded as a weed, B. ramosa is still cultivated as a minor crop in some areas of southern India for both human and animal consumption $^{21}$. Similarly, an edible form of D. cruciata (also identified in low numbers at Suabarei) is grown by the Khasi Hill tribals of Meghalaya for its grains ${ }^{22}$. According to Singh and Arora ${ }^{23}$, this crop is rainfed and cultivated by the hill tribes in a mixed cropping system with maize. As with browntop millet, this species is also a common agricultural weed.

All of the crops identified at Suabarei represent kharif/ summer crops without any traces of winter crops. This inference corresponds with the data from Golbai Sasan originally studied by Kajale and Sinha, which led to the identification of rice (O. sativa, Oryza sp.), impressions of rice husks on pottery and horse gram, etc. It also accords well with the data collected by Harvey ${ }^{24}$, and Kingwell-Banham et al. ${ }^{25}$ from Golbai Sasan and Gopalpur. They suggested that either the summer monsoon rainfall was adequate enough during this period, as it is today, to allow for the production of rice that would provide food throughout the year (a system that would free up labour during the winter months for other activities, e.g. crafts or mining), or that two seasons of rice cropping were practised (kharif/summer and rabi/winter). As yet, no grain storage systems have been identified in NeolithicChalcolithic Odisha; however, the number of excavations is low and large-scale horizontal excavations that would uncover multiple structures within these villages have not yet been conducted.

\section{Conclusion}

The archaeobotanical remains recovered from the stratified layers of four trenches belonging to the Chalcolithic phase show that the people of Chalcolithic Suabarei grew rice, protein-rich pulses like horse gram and green gram/ mung bean, and also ate jujube fruits and nuts. While this archaeobotanical dataset is the source of limited information relating to food habits and ancient agricultural systems at this site, these findings represent the accumulation of knowledge on the plant-based subsistence of prehistoric Odisha.

1. Subramanian, T. S., Odisha's neolithic pre-history. Frontline, June 2018; http://www.frontline.in/arts-and-culture/heritage/odishas-neolithic-prehistory/article9103740.ece (accessed on 11 June 2018). 
2. Subramanian, T. S., Suabarei surprise. Frontline, September 2016; https://www.frontline.in/arts-and-culture/heritage/suabareisurprise/article9103630.ece (accessed on 11 June 2018).

3. Basa, K. K. and Mohanty, P., Archaeology of Orissa, Pratibha Prakashan, Delhi, 2000.

4. Mohanty, R. K. et al., Preliminary report on exploration at Golbai Sasan, Talapada and the surrounding area, Dist. Khurda, Odisha, 2010-11. Bull. Deccan Coll. Pune, 2012-2013, 72-73, 153-166.

5. Behera, P. K., Excavations at Khameswaripali-a proto Historic settlement in the middle Mahandi valley, Orissa: a preliminary report. Pragdhara, 2000-2001, 11, 13-34.

6. Kar, S. K., Basa, K. K. and Joglekar, P., Explorations at Gopalpur, District Nayagarh, Coastal Orissa. Man Environ., 1998, 23, 107114.

7. Kar, S. K., Gopalpur: a Neolithic-Chalcolithic site in coastal Orissa. In Archaeology of Orissa (eds Basa, K. K. and Mohanty, P.), Pratibha Prakashan, Delhi, 2000, pp. 368-391.

8. Mohanty, B., Golbai: a new horizon in Orissan archaeology. Orissa Hist. Res. J., 1994, 39(1), 30-32.

9. Sinha, B. K., Golbai: A protohistoric site on the coast of Orrisa. In Archaeology of Orissa (eds Basa, K. K. and Mohanty, P.), Pratibha Prakashan, Delhi, 2000, pp. 322-355.

10. Kingwell-Banham, E., Petrie, C. A. and Fuller, D. Q., Early agriculture in South Asia. In The Cambridge World History, Cambridge University Press, Cambridge, UK, 2015, pp. 261-288; doi:10.1017/CBO9780511978807.

11. Joglekar, P. P. and Patnaik, J. K., Faunal remains from the Chalcolithic contexts at Suabarei, District Puri, Odisha. Bull. Deccan College Res. Inst., 2016, 76, 29-44.

12. Fuller, D. Q., Castillo, C., Kingwell-Banham, E., Qin, L. and Weisskopf, A., Charred pomelo peel, historical linguistics and other tree crops: approaches to framing the historical context of early citrus cultivation in East, South and Southeast Asia. In The History and Archaeology of the Citrus Fruit from the Far East to the Mediterranean: Introductions, Diversifications, Uses (eds Zech, V., Fiorentino, G. and Coubray, S.), Centre Jean Bérard, Naples, Italy, 2018, pp. 31-50; https://books.openedition.org/ $\mathrm{pcjb} / 2173$.

13. Pearsall, D. M., Paleoethnobotany: A Handbook of Procedures, Routledge, London, 2009, 2nd edn.

14. Cappers, R. T. J., Neef, R. and Bekker, R. M., Digital Atlas of Economic Plants, Barkhuis Publishing, Eelde, The Netherlands, 2009.

15. Fuller, D. Q. and Harvey, E., The archaeobotany of Indian pulses: identification, processing and evidence for cultivation. Environ. Archaeol., 2006, 11, 219-246.

16. Saraswat, K. S., Plant economy of early farming communities. In Early Farming Communities of the Kaimur (Excavations at Senuwar) (ed. Singh, B. P.), Publication Scheme, Jaipur, 2004, pp. 416-535.

17. Kingwell-Banham, E., Karoune nee. Harvey, E., Mohanty, R. K. and Fuller, D. Q., Archaeobotanical investigations into Golbai Sasan and Gopalpur, two Neolithic-chalcolithic settlements of Odisha. Ancient Asia, 2018, 9(5), 1-14; doi:http://doi.org/10.5334/ aa.164.
18. Castillo, C. C. et al., Archaeogenetic study of prehistoric rice remains from Thailand and India: evidence of early Japonica in South and Southeast Asia. Archaeol. Anthropol. Sci., 2016, 8(3), 523-543; doi:10.1007/s12520-015-02236-5.

19. Fuller, D. Q. and Murphy, C., The origins and early dispersal of horsegram (Macrotyloma uniflorum), a major crop on ancient India. Genet. Resour. Crop Evol., 2018, 65, 285; https://doi.org/ 10.1007/s10722-017-0532-2.

20. Harvey, E. L., Fuller, D. Q., Basa, K. K., Mohany, R. and Mohanta, B., Early agriculture in Orissa: some archaeobotanical results and field observations on the Neolithic. Man Environ., 2006, 31, 2132 .

21. Kimata, M., Ashok, E. G. and Seetharam, A., Domestication, cultivation and utilization of two small millets, Brachiaria ramosa and Setaria glauca (Poaceae), in South India. Econ. Bot., 2000, 54(2), 217-227.

22. Bor, N. L., Flora of Assam. Gramineae, BSI, Calcutta, 1940, vol. 5, pp. 205-207.

23. Singh, H. B. and Arora, R. K., Raishan (Digitaria sp.): a minor millet of the Khasi Hills, India. Econ. Bot., 1972, 26(4), 376-380.

24. Harvey, E. L., Early agriculture communities in northern and eastern India: an archaeobotanical investigation. Unpublished Ph D thesis. Institute of Archaeology, University of London, UK, 2006.

25. Kingwell-Banham, E., Early rice agriculture in South Asia. Identifying cultivation systems using archaeobotany. Ph D thesis, University College, London, UK, 2015.

26. Bronk Ramsey, C., Bayesian analysis of radiocarbon dates. Radiocarbon, 2009, 51(1), 337-360.

27. Reimer, Inter Cal13 and MARINE13 radiocarbon age calibration curves 0-50,000 years cal BP. Radiocarbon, 2013, 55(4), 18691887; doi:10.2458/azu_js_rc.55.16947.

28. Oxford Radiocarbon Accelerator Unit, University of Oxford, https://c14.arch.ox.ac.uk/embed.php?File=oxcal.html (accessed on 10 September 2015).

29. QGIS Development Team, QGIS 2.12.3-Lyon 2015. QGIS Geographic Information System. Open Source Geospatial Foundation Project; http://www.qgis.org/ (accessed on 20 May 2018).

ACKNOWLEDGEMENTS. S.N. thanks Prof. V. S. Shinde (ViceChancellor, Deccan College Post-Graduate and Research Institute (Deemed to be University), Pune) for providing the necessary facilities to carry out this work. He also thanks Prof. K. Paddayya (former Director and Emeritus Professor, Deccan College, Pune) for his valuable suggestions. J.B.K. thanks the authorities of Archaeological Survey of India for access to samples. E.K.B., C.M. and D.Q.F. were supported by the European Research Council Grant No. 323842 'Comparative pathways to agriculture' (2013-2018).

Received 11 August 2018; revised accepted 29 January 2019

doi: $10.18520 / \mathrm{cs} / \mathrm{v} 116 / \mathrm{i} 8 / 1373-1380$ 